\title{
THE EFFECTS OF GYTTJA ON SOIL PROPERTIES IN NICKEL- CONTAMINATED SOILS
}

\author{
KARACA, S. ${ }^{*}{ }^{*}$ - GÜlSER, F. ${ }^{1}-$ SÖNMEZ, F. ${ }^{2}-$ GÖKKAYA, T. H. ${ }^{1}$ \\ ${ }^{1}$ Department of Soil Science and Plant Nutrition, Yüzüncü Yll University, 65080 Van, Turkey \\ ${ }^{2}$ Seed Science and Technology, Bolu Abant Izzet Baysal University, 1400 Bolu, Turkey \\ *Corresponding author \\ e-mail: s.karaca@yyu.edu.tr; phone: +90-432-225-1056; fax: +90-432-225-1104
}

(Received $25^{\text {th }}$ Oct 2018; accepted $7^{\text {th }}$ Jan 2019)

\begin{abstract}
In this study, the effects of gyttja on some soil properties in two different nickel-contaminated soils (Inceptisol and Entisol) were investigated. This study was conducted with the application of three levels of gyttja $(0,5$ and $10 \%)$ in two different soils (Inceptisol and Entisol) contaminated with $\mathrm{Ni}$ at three levels of concentration $\left(0,40\right.$ and $\left.80 \mathrm{mg} \mathrm{kg}^{-1}\right)$ in a factorial experimental design with three replications. Some soil properties showed differences in different nickel and gyttja applications. Soil nickel content significantly $(\mathrm{P}<0.01)$ increased in nickel-contaminated soils. Soil organic matter and phosphorus contents in gyttja applicated soils were found to reach higher levels compared to those without gyttja application.
\end{abstract}

Keywords: organic material, heavy metal, soil properties, Inceptisol, Entisol

\section{Introduction}

Heavy metals natural components of the Earth's crust, the concentration of several heavy metals can reach toxic levels due to consequence of anthropogenic activities. Heavy metals are recognized as important environmental contaminants in industrialized societies. Heavy metal contamination is originated from local sources, mostly industry, agriculture, waste incineration, combustion of fossil fuels and road traffic (Farid et al., 2015). Fifty three elements are in the heavy metal category and defined as the group of elements whose densities are higher than $5 \mathrm{~g} \mathrm{~cm}^{3}$ (Özbolat and Tuli, 2016).

Nickel is one of the most important heavy metal in terms of its potential toxicity to plants and animals (Kabata-Pendias and Pendias, 2001). Although nickel has been recognized as essential micronutrient in plant cells (Ankel-Fuchs and Thaver, 1988), its excess has destructive effect on plant growth, causing disturbances in photosynthesis, destruction of cell membranes and damages of cells (Pandolfini et al., 1992). Baranowska-Morek (2003) reported that the presence of heavy metals can induce deficiency of the elements necessary for proper plant development similarly. It was reported that high concentrations of heavy metals cause an imbalance of nutrients and have an adverse effect on the synthesis and functioning of many enzymes, vitamins and hormones (Luo and Rimmer, 1995).

It was reported that mobility and availability of heavy metals are controlled by adsorption and desorption characteristics of soils (Krishnamurti et al., 1999). The soil properties including $\mathrm{pH}$, cation exchange capacity, organic matter content, clay minerals contents, lime and $\mathrm{Fe}$ and $\mathrm{Mn}$ oxides play important role in adsorption and desorption of heavy metals (Antoniadis et al., 2008; Usman et al., 2008).

Organic matter has been implicated for alleviating bioavailability of heavy metals in soils recently soil organic matter has been of particular interest in researches of heavy metal sorption by soils, because of transformation of metal cations to stable complexes 
form with organic ligands (Elliott et al., 1986). Organic matter makes strong complexes with heavy metals (Bloom, 1981). Khan et al. (2000) reported that amendment of contaminated soils with organic matter decreased bioavailability of heavy metals.

The humic substances, the major component of soil organic matter, have effects on various biochemical outcomes in plant tissue and soil properties such as aggregation, aeration, permeability, water holding capacity, micronutrient transport and availability (Tan, 2003). Among the deposits of humic substances, gyttja, which is a semi-formed lignite coal cover layer and its content of organic matter, can change from 6 to $40 \%$ by weight (Demirkıran et al., 2008). In the other researchers reported that gyttja which low-cost and locally available natural materials is a mixture organic and inorganic materials as calcareous and clay, its content of organic matter generally varied from 40 to $50 \%$ by weight, and located on lignite deposits. The gyttja which is not used in the coal-fired power plant due to its low quality must be removed for the lignite layer can be taken for mining (Saltalı et al., 2015).

In this study, the effects of gyttja on some soil properties and nickel content in nickel-contaminated two different soils (Inceptisol and Entisol) were investigated.

\section{Material and methods}

This study was conducted with the pots having $2 \mathrm{~kg}$ different soils (Inceptisol and Entisol) in a plant growth room. Experimental soils were taken from depth of 0-20 cm in Van province, east of Turkey. The Inceptisol soil used in this study had a clay loam texture, non saline, and neutral, limely, insufficient in organic matter (OM), sufficient in phosphorus $(\mathrm{P})$ and potassium $(\mathrm{K})$ contents. The Entisol soil used in this study had a silty loam texture, non saline, slightly alkaline, limely, insufficient in organic matter and $\mathrm{P}$ contents and sufficient in K content (Table 1).

Table 1. Some properties of Inceptisol and Entisol soil

\begin{tabular}{|c|c|c|c|}
\hline \multirow{2}{*}{\multicolumn{2}{|c|}{ Analyses }} & \multicolumn{2}{|c|}{ Soil types } \\
\hline & & Inceptisol & Entisol \\
\hline \multicolumn{2}{|l|}{$\mathrm{pH}$} & 7.41 & 7.64 \\
\hline \multicolumn{2}{|l|}{ Texture } & Clay loamy & Silt loamy \\
\hline Lime & \multirow{2}{*}{$\%$} & 2.03 & 2.27 \\
\hline Organic matter & & 1.03 & 1.70 \\
\hline Salinity & $\mu \mathrm{S} \mathrm{cm}^{-1}$ & 120 & 118 \\
\hline Phosphorus (P) & \multirow{8}{*}{$\mathrm{mg} \mathrm{kg}^{-1}$} & 7.20 & 4.40 \\
\hline Potassium (K) & & 35 & 35 \\
\hline Calcium $(\mathrm{Ca})$ & & 696 & 594 \\
\hline Magnesium (Mg) & & 70 & 24 \\
\hline Iron $(\mathrm{Fe})$ & & 1.96 & 1.05 \\
\hline Manganese (Mn) & & 3.53 & 4.64 \\
\hline Zinc $(\mathrm{Zn})$ & & 0.15 & 0.16 \\
\hline Copper $(\mathrm{Cu})$ & & 0.42 & 0.33 \\
\hline
\end{tabular}

After filling each pot without drainage holes with two different soils, 54 pots were autoclaved. Three levels of gyttja $(0,5,10 \%)$ were applied into pots including two 
different soils contaminated with three levels of nickel (Ni) $\left(0,40\right.$ and $\left.80 \mathrm{mg} \mathrm{kg}^{-1}\right)$ in factorial experimental design with three replications. The planned doses of gyttja were directly mixed the each pot. Nickel doses were applied as their solutions prepared by using distilled water. Yedikule lettuce cultivar was used as experimental plant. The lettuce seedling having three leaves planted to each pot. This experiment was carried out within 65 days. At the end of experiment firstly it was determined that increasing gyttja doses had the positive effects on plant growth criteria of lettuce in $\mathrm{Ni}$ contaminated soils. Conversely, Ni applications decreased the means of plant growth criteria (Gülser et al., 2017). Secondly effects of gyttja on some soil properties in nickel-contaminated soils were determined by using following soil analyses methods.

The gyttja used in this study had neutral $\mathrm{pH}$ (7.28), $0.71 \mathrm{dS} \mathrm{m}^{-1}$ in salinity, $51.3 \%$ in organic matter $(\mathrm{OM})$ content, $1.88 \%$ in nitrogen $(\mathrm{N}), 0.11 \%$ total $\mathrm{P}$ content and $55.12 \%$ in humic acids.

Some soil physical and chemical properties of soil were determined as follows; $\mathrm{pH}$ in 1:1 soil water suspension by $\mathrm{pH}$ meter (Jenway, 3310), salt content in the same suspension by EC meter (YSI 3100), organic matter by modified Walkey-Black, lime content by Scheibler calcimeter, phosphorus with Olsen bicarbonate method by spectrophotometer (Shimadzu UV mini 1240), potassium (K), calcium (Ca) and magnesium $(\mathrm{Mg})$ by the extraction with $1 \mathrm{~N}$ neutral ammonium acetate and heavy metal by extraction with a mixture of nitric acid and perchloric acid in 2:1 ratio by using atomic absorption spectrophotometer (Thermo 1CE 3000 series) according to Kacar and İnal (2008).

Statistical analyses was done using SAS package program (SAS Institute, 1989) to show difference among the mean values of some soil properties and some nutrient contents from the different applications.

\section{Result and discussion}

The results of variance analyses for the some soil properties are given in Table 2.

Table 2. F values of the variance analyses for the some soil properties

\begin{tabular}{c|c|c|c|c|c|c|c|c|c|c}
\hline V.S. & DF & $\mathbf{p H}$ & $\mathbf{E C}$ & Lime & $\mathbf{O . M}$ & $\mathbf{P}$ & $\mathbf{K}$ & $\mathbf{C a}$ & $\mathbf{M g}$ & $\mathbf{N i}$ \\
\hline Soil (A) & 1 & $18.94^{* *}$ & $0.26 \mathrm{~ns}$ & $9.73^{*}$ & $8.36^{*}$ & $0.02 \mathrm{~ns}$ & $4.03 \mathrm{~ns}$ & $66.58^{* *}$ & $1001.06^{* *}$ & $907.22^{* *}$ \\
Gyttja(B) & 2 & $14.89^{* *}$ & $7.47^{*}$ & $15.23^{* *}$ & $107.60^{* *}$ & $0.90 \mathrm{~ns}$ & $2.80 \mathrm{~ns}$ & $92.76^{* *}$ & $0.14 \mathrm{~ns}$ & $10.10^{* *}$ \\
$\mathrm{Ni}(\mathrm{C})$ & 2 & $4.12 \mathrm{~ns}$ & $1.51 \mathrm{~ns}$ & $0.32 \mathrm{~ns}$ & $2.46 \mathrm{~ns}$ & $1.24 \mathrm{~ns}$ & $3.58 \mathrm{~ns}$ & $4.24 \mathrm{~ns}$ & $1.65 \mathrm{~ns}$ & $6.07^{*}$ \\
$\mathrm{AxB}$ & 2 & $3.75 \mathrm{~ns}$ & $0.08 \mathrm{~ns}$ & $7.23 \mathrm{~ns}$ & $9.09^{* *}$ & $1.91 \mathrm{~ns}$ & $8.80^{* *}$ & $1.04 \mathrm{~ns}$ & $0.87 \mathrm{~ns}$ & $5.74^{*}$ \\
$\mathrm{AxC}$ & 2 & $1.02 \mathrm{~ns}$ & $0.10 \mathrm{~ns}$ & $1.92 \mathrm{~ns}$ & $0.37 \mathrm{~ns}$ & $6.36^{*}$ & $2.77 \mathrm{~ns}$ & $1.81 \mathrm{~ns}$ & $4.52^{*}$ & $1.91 \mathrm{~ns}$ \\
BxC & 4 & $0.64 \mathrm{~ns}$ & $0.25 \mathrm{~ns}$ & $1.37 \mathrm{~ns}$ & $0.72 \mathrm{~ns}$ & $0.82 \mathrm{~ns}$ & $5.73^{*}$ & $1.35 \mathrm{~ns}$ & $2.86 \mathrm{~ns}$ & $3.80^{*}$ \\
AxBxC & 4 & $5.42^{*}$ & $0.85 \mathrm{~ns}$ & $2.07 \mathrm{~ns}$ & $0.84 \mathrm{~ns}$ & $4.27 *$ & $2.74 \mathrm{~ns}$ & $1.66 \mathrm{~ns}$ & $1.19 \mathrm{~ns}$ & $1.51 \mathrm{~ns}$ \\
\hline
\end{tabular}

*significant at 0.05 level, **significant at 0.01 level, ns: non significant

Soil types had significant $(\mathrm{P}<0.01)$ effects on $\mathrm{pH}, \mathrm{Ca}, \mathrm{Mg}, \mathrm{Ni}$ contents. Lime, OM contents were also significantly $(\mathrm{P}<0.05)$ influenced by the soil types. Gyttja treatments significantly affected $\mathrm{pH}$, lime, OM, Ca, Ni contents $(\mathrm{P}<0.01)$, EC $(\mathrm{P}<0.05)$ contents. Ni applications had no effects soil properties expect Ni contents $(\mathrm{P}<0.01)$. Interactions of soil type and gyttja had significantly $(\mathrm{P}<0.01)$ effects on $\mathrm{OM}, \mathrm{K}$ and $(\mathrm{P}<0.05) \mathrm{Ni}$ contents. The effects of soil type and $\mathrm{Ni}$ interactions were found significant at 5\% level in $\mathrm{P}$ and $\mathrm{Mg}$ contents; $\mathrm{Ni}$ and gyttja interactions had 
significantly $(\mathrm{P}<0.05)$ effects on $\mathrm{K}$ and $\mathrm{Ni}$ contents. The effects of soil type, gyttja and $\mathrm{Ni}$ had significantly $(\mathrm{P}<0.05)$ effects on $\mathrm{pH}$ level and $\mathrm{P}$ contents (Table 2$)$.

$\mathrm{EC}, \mathrm{OM}, \mathrm{Ca}$ and $\mathrm{Ni}$ contents increased by increasing gyttja doses though $\mathrm{pH}$ and lime decreased. These increases were significant statistically. The highest means of EC, $\mathrm{OM}, \mathrm{Ca}, \mathrm{Mg}$ and $\mathrm{Ni}$ contents were obtained as $1607.63 \mu \mathrm{S} \mathrm{cm}^{-1}, 6.49 \%, 8618 \mathrm{mg} \mathrm{kg}^{-1}$, $541.38 \mathrm{mg} \mathrm{kg}^{-1}, 63.59 \mathrm{mg} \mathrm{kg}^{-1}$ in $10 \%$ gyttja treatment respectively (Figs. 1-6). Gyttja used in this study had lower $\mathrm{pH}$ value than those in experimental soils. Therefore gyttja applications may be decrease $\mathrm{pH}$ value of soils of growing media.

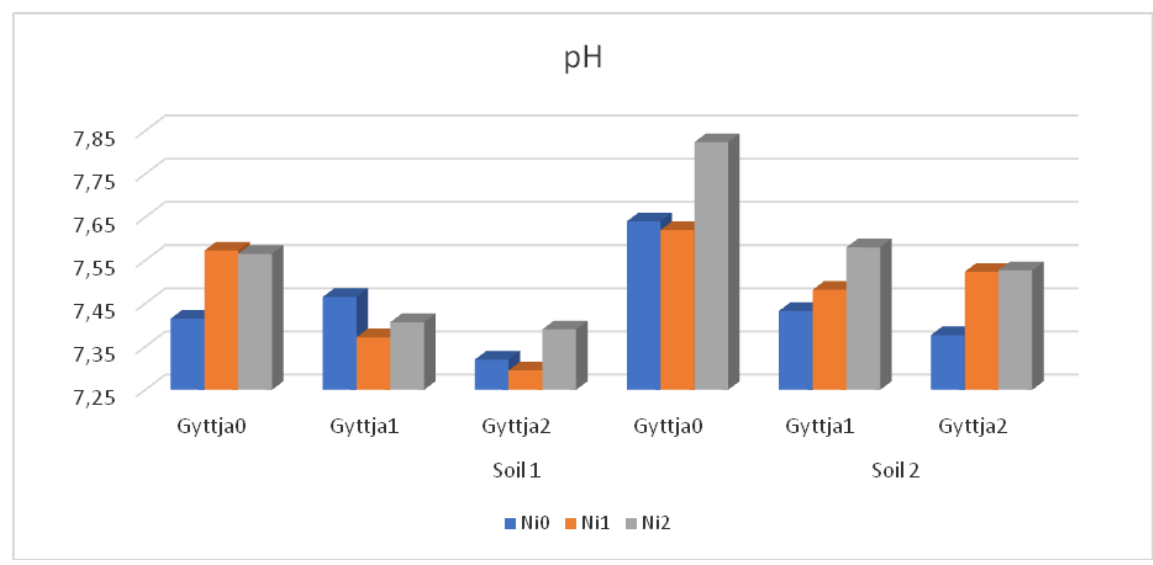

Figure 1. Effects of different gyttja level $(P<0.01)$ and nickel doses (ns) on $\mathrm{pH}$. Gyttja0: 0\%, Gyttjal: 5\%, Gyttja2: 10\%, NiO: $0 \mathrm{mg} \mathrm{Ni} \mathrm{kg}{ }^{-1}$, Nil: $40 \mathrm{mg} \mathrm{Ni} \mathrm{kg}^{-1}$, Ni2: $80 \mathrm{mg} \mathrm{Ni} \mathrm{kg}{ }^{-1}$, LSDsoil $(P<0.05): 0.05$, LSDgyttja $(P<0.05): 0.05$ LSDnickel $(P<0.05): 0.04$

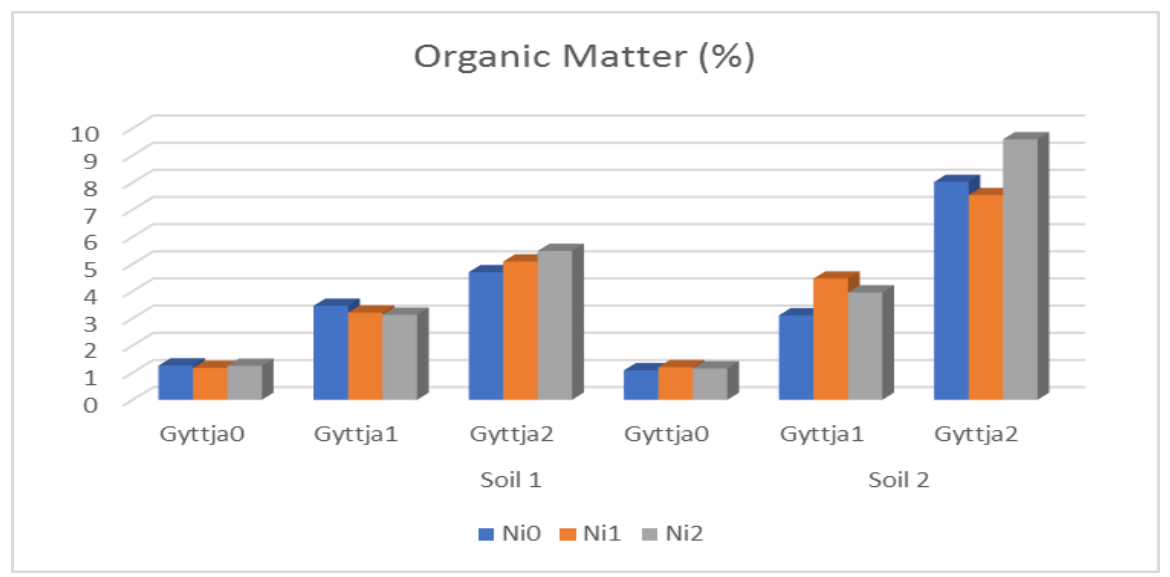

Figure 2. Effects of different gyttja level $(P<0.01)$ and nickel doses $(n s)$ on organic matter. Gyttja0: 0\%, Gyttja1: 5\%, Gyttja2: 10\%, Soil1: Inceptisol, Soil2: Entisol, NiO: $0 \mathrm{mg} \mathrm{Ni} \mathrm{kg}{ }^{-1}$, Nil: $40 \mathrm{mg} \mathrm{Ni} \mathrm{kg}^{-1}$, Ni2: $80 \mathrm{mg} \mathrm{Ni} \mathrm{kg}^{-1}$, LSDsoil (P < 0.05): 0.38, LSDgyttja $(P<0.05)$ : 0.38, LSDnickel $(P<0.05): 0.31$

The means of some soil properties determined in Entisol soil were significantly higher than those in Inceptisol soil (Figs. 1-6). Ni contents means obtained in Entisol soil were also higher than those in Inceptisol soil in ratio of $22.67 \%$. It was thought that differences in Ni contents among two soil types caused by differences in soil properties. The $\mathrm{pH}$ value and $\mathrm{OM}$ content of Entisol soil were in higher level than those in 
Inceptisol soils. Zhao et al. (2010), reported that soil $\mathrm{pH}$ was found to play the most important role in determining metal speciation, solubility from mineral surfaces, movement and bioavailability of metals in the soil solution. The Entisol soil used in this study had higher $\mathrm{pH}$ and OM content according to Inceptisol soil. Ramachandran and D'Souza (2013) determinate that Ni adsorption capacity of the soil increased with an increase in $\mathrm{pH}$ of the soil. On the other hand $\mathrm{OM}$ is a major factor to the availability of soils for retaining heavy metals in exchangeable form (Mc Cauley et al., 2009).

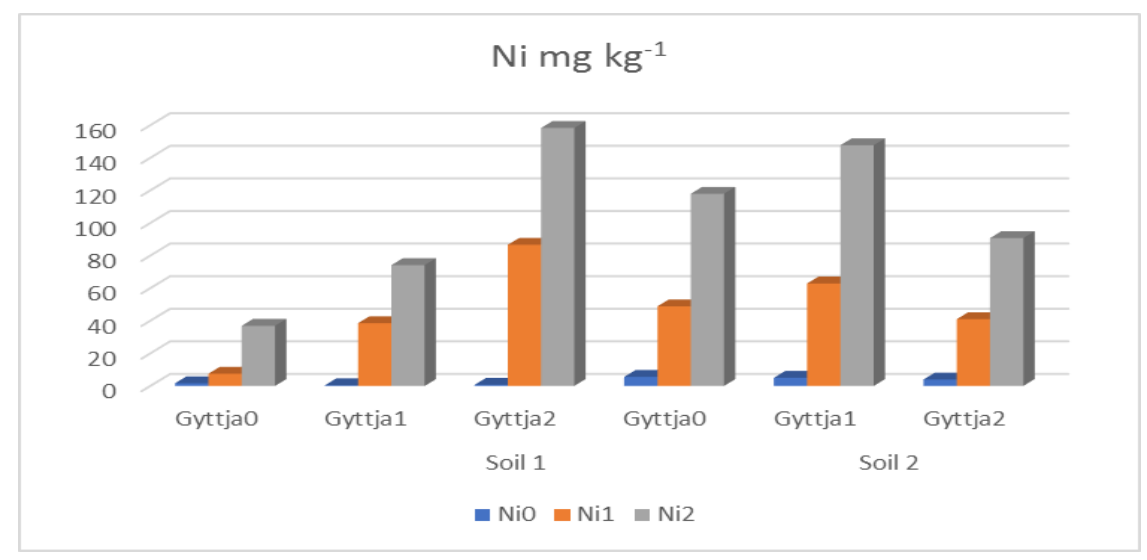

Figure 3. Effects of different gyttja level $(P<0.01)$ and nickel doses $(P<0.01)$ on nickel content. Gyttja0: 0\%, Gyttja1: 5\%, Gyttja2: 10\%, Soill: Inceptisol, Soil2: Entisol, Ni0: 0 mg Ni

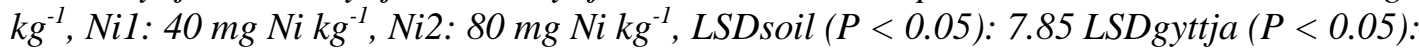
7.85, LSDnickel $(P<0.05): 6.41$

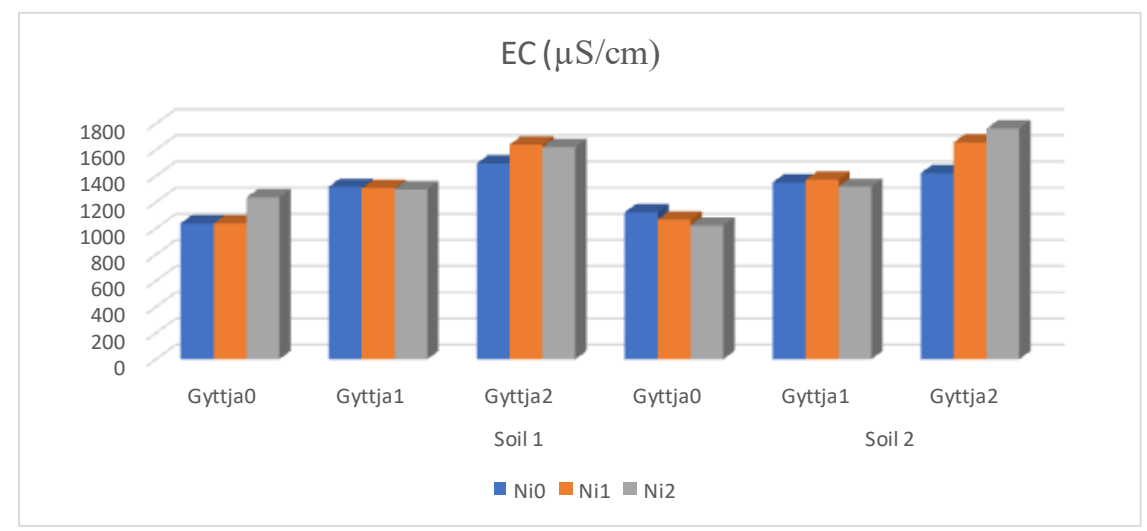

Figure 4. Effects of different gyttja level $(P<0.05)$ and nickel doses $(n s)$ on EC. Gyttja0: 0\%, Gyttja1: 5\%, Gyttja2: 10\%, Soill: Inceptisol, Soil2: Entisol, NiO: $0 \mathrm{mg} \mathrm{Ni} \mathrm{kg}{ }^{-1}$, Nil: $40 \mathrm{mg} \mathrm{Ni}$

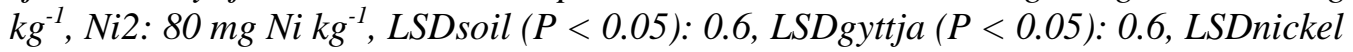
$(P<0.05): 0.5$

Similarly, high EC level of Gyttja used in this study may be lead to increase in EC levels of growing media. Numerous studies demonstrated that humic substances such as gyttja and leonardite increased soil organic matter content. Ece et al. (2007) reported that leonardit applications did not changed $\mathrm{pH}$, lime content and EC significantly while OM content of growth media soils added leonardit increased significantly. Similarly, it was also reported that gyttja applications to soil significantly increased soil organic 
matter content (Karaca et al., 2006; Turgay et al., 2011; Gülser et al., 2014; Saltalı and Eryiğit, 2015). Turgay et al. (2011) reported that gyttja as humic substances added to the soil did not affected soil parameters and macro nutrient contents. Applying of organic materials (barnyard manure, poultry manure, sewage sludge, leonardite, gyttja etc.) is a commend practice to increase OM content (Stevenson, 1994). Decomposition of such organic materials added to soil enhance energy source and this stimulate soil microbial activity (Fließbach and Mäder, 2000) which finally accelerates the conversions of added organic materials to the background soil organic matter. It was known that humic substances play a critical role in increasing soil organic matter content having useful effects on soil structure, water-holding capacity, adsorption and retention complexes and are responsible for increasing stable carbon levels in soil (Paulin and Q'Malley, 2008).

Generally, nickel contents of soil were higher than critical level $\left(50 \mathrm{mg} \mathrm{kg}^{-1}\right)$ reported by Bergman (1992) in $80 \mathrm{mg} \mathrm{kg}^{-1}$ gyttja applications in both soil types. It was thought that high organic matter contents gyttja applied soils caused retention of $\mathrm{Ni}$.

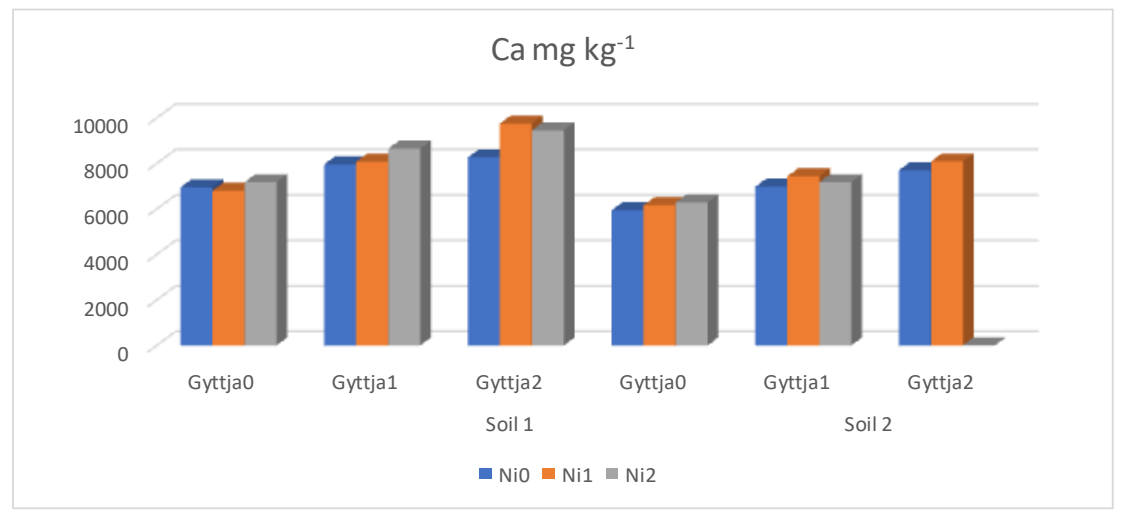

Figure 5. Effects of different gyttja level $(P<0.01)$ and nickel doses (ns) on Ca. Gyttja0: 0\%, Gyttjal: 5\%, Gyttja2: 10\%, Soill: Inceptisol, Soil2: Entisol, NiO: $0 \mathrm{mg} \mathrm{Ni} \mathrm{kg}{ }^{-1}$, Nil: $40 \mathrm{mg} \mathrm{Ni}$ $\mathrm{kg}^{-1}$, Ni2: $80 \mathrm{mg} \mathrm{Ni} \mathrm{kg}^{-1}$, LSDsoil $(P<0.05): 220$, LSDgyttja $(P<0.05): 220$, LSDnickel $(P<0.05): 179$

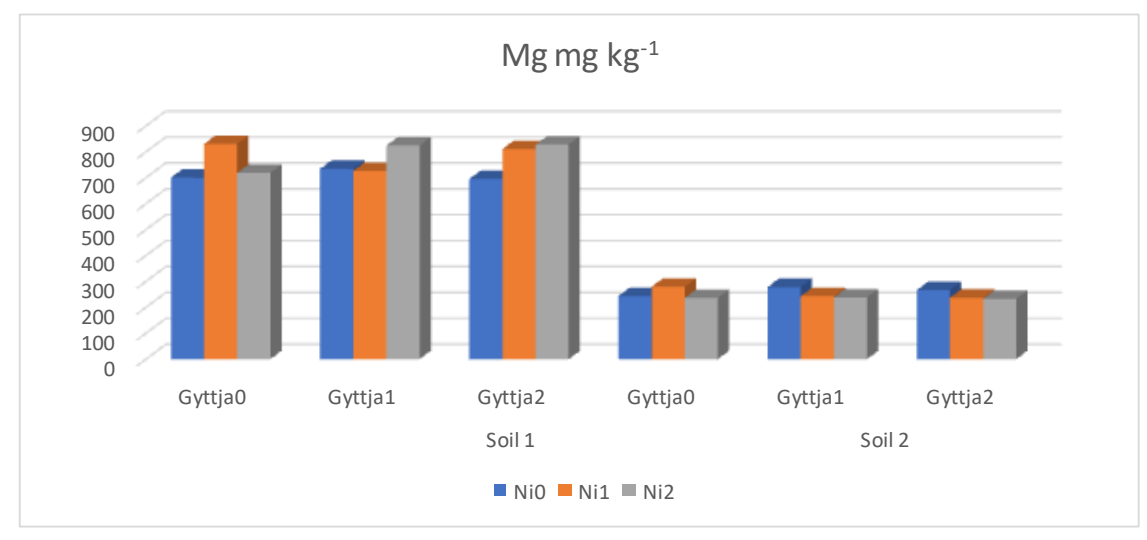

Figure 6. Effects of different gyttja level (ns) and nickel doses (ns) on Mg. Gyttja0: 0\%, Gyttja1: 5\%, Gyttja2: 10\%, Soill: Inceptisol, Soil2: Entisol, NiO: $0 \mathrm{mg} \mathrm{Ni} \mathrm{kg}^{-1}$, Nil: $40 \mathrm{mg} \mathrm{Ni}$

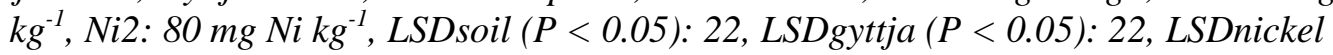
$(P<0.05): 18$ 
The Ni applications increased significantly Ni contents of soils. Nickel contents of control soils were determined at low levels in both soil types. The doses of gytjja $10 \%$ had more positive effect to prevent nickel contamination in Entisol soil according to those in Inceptisol soil (Fig. 3). Apart from soil pH, organic matter content in soils is also one of the most important soil properties affecting heavy metal availability (Mc Cauley et al., 2009).

Antoniadis et al. (2008) and Mc'Cauley et al. (2009), Bai et al. (2008), reported that organic matter is a major factor to the ability of soils for retaining heavy metals in exchangeable form. They also determined that heavy metal adsorption onto soil constituents declined while soil organic matter content decreased. Organic matter supplies organic chemicals to the soil solution. These organic chemicals can serve as chelate and increase metal availability to plants.

The lowest and highest Ni means of Inceptisol soil were obtained as $2.92 \mathrm{mg} \mathrm{kg}^{-1}$ and $158 \mathrm{mg} \mathrm{kg}^{-1}$ control and G2, in while the lowest and highest $\mathrm{Ni}$ means of Entisol soil were in control and G1 application as $8 \mathrm{mg} \mathrm{kg}^{-1}$ and $142 \mathrm{mg} \mathrm{kg}^{-1}$, respectively (Fig. 3).

In this study, increasing gyttja doses decreased Ni contents according to control in Entisol soil with $10 \%$ gyttja applications in Inceptisol soils. Karaca et al. (2006) reported that gyttja application decreased Ni concentrations of soil among 90th-180th day following applying time. In this regard, applying gyttja to soil contaminated with $\mathrm{Ni}$ can decrease the availability of nickel.

\section{Conclusion}

As a result, $10 \%$ gyttja application decreased $\mathrm{Ni}$ contents according to control in Inceptisol and Entisol soils. The organic matter contents of experimental soils increased by increasing gyttja doses. These increases were found at higher level in Entisol soils than those in Inceptisol soils. Similarly increasing gyttja doses increased EC values in both soil types without causing of salinity problem. According to results of this study $10 \%$ gyttja application was suggested to increase the soil matter contents and to decrease damages of heavy metals in plants growing nickel polluted soils. On the other hand it was thought that gyttja doses using to prevent heavy metal damages may be show the changes according to soil type, plant variety and kind of heavy metal and degree of heavy metal pollution in soil. So, determination of the beneficial effects of gyttja in heavy metal contaminated soils needs the more researches in long-term experiments.

\section{REFERENCES}

[1] Ankel-Fuchs, S., Thaver, R. K. (1988): Nickel in Biology: Nickel as an Essential Trace Element. - In: Lancaster, J. R. (eds.) The Bioinorganic Chemistry of Nickel. VCH, Weinheim, pp: 93-110.

[2] Antoniadis, V., Robinson, J. S., Alloway, B. J. (2008): Effects of short-term pH fluctuations on cadmium, nickel, lead, and zinc availability to ryegrass in a sewage sludge-amended field. - Chemosphere 71: 759-764.

[3] Baranowska Morek, A. (2003): Roślinne mechanizmy tolerancji na toksyczne dzialanie metali cieżkich - Kosmos 52(2-3): 283-298.

[4] Bergman, W. (1992): Nutritional Disorders of Plants. - Gustav Fischer, New York. 
[5] Bloom, P. R. (1981): Phosphorus adsorption by an aluminum-peat complex. - Soil Science Society of America Journal 45: 267-272.

[6] Demirkıran, A. R., Akkaya, A., Türkmener, M. F., Türkmener, M. Ç., Akkaya, S. (2008): Toprak verimliliğini arttırmada kullanılabilecek alternatif organik bir materyal: Gidya (Gyttja). - Dünya Su Forumu, Sulama-Tuzlanma Toplantısı, Bildiri Şanlıurfa, Türkiye. 5: 159-168.

[7] Ece, A., Saltal1, K., Eryiğit, N., Uysal, F. (2007): The Effects of Leonardite Applications on Climbing Bean (Phaseolus vulgaris L.) Yield and the some soil properties. - Journal of Agronomy 6: 480-483.

[8] Elliott, H. A., Liberati, M. R., Huang, C. P. (1986): Competitive adsorption of heavy metals by soils. - Journal of Environmental Quality 15: 214-219.

[9] Farid, G., Sarwar, N., Saifullah, A. A., Ghafoor, A., Rehman, M. (2015): Heavy metals $(\mathrm{Cd}, \mathrm{Ni}$ and $\mathrm{Pb})$ contamination of soils, plants and waters in Madina town of Faisalabad metropolitan and preparation of GIS based maps. - Advances in Crop Science and Technology 4: 199. DOI: 10.4172/2329-8863.1000199.

[10] Fließbach, A., Mäder, P. (2000): Microbial biomass and size-density factions differ between soils of organic and conventional agricultural systems. - Soil Biology and Biochemistry 32: 757-768.

[11] Gülser, F., Yılmaz, C., Sönmez, F. (2014): Gidya ve kimyasal gübre uygulamalarının yetiştirme ortamı ile biber (Capsicum annuum 1.) bitkisinde meyvelerin pomolojik ve biyokimyasal özelliklerine etkileri. - Toprak Bilimi ve Bitki Besleme Dergisi 2(1): 1.

[12] Gülser, F., Sönmez, F., Karaca, S., Gökkaya, T. H. (2017): The effects of gytjja on plant growth and nickel contents of lettuce (Lactuca sativa) in nickel-contaminated soils. Fresenius Environmental Bulletin 26(4): 2992-2997.

[13] Kabata-Pendias, A., Pendias, H. (2001): Trace Elements in Soil and Plants. 3rd Edition CRC Press, Boca Raton, FL.

[14] Kacar, B., Inal, A. (2008): Plant Analysis. - Nobel Publication, Ankara.

[15] Karaca, A., Turgay, O. C., Tamer, N. (2006): Effects of a humic deposit (gyttja) on soil chemical and microbiological properties and heavy metal availability. - Biology and Fertility of Soils 42(6): 585-592.

[16] Khan, G., Kuek, C., Chaudhary, T., Fhoo, C., Hayes, W. (2000): Role of mycorrhizae and phytochelators in heavy metal contaminated land remediation. - Chemosphere 41: 197207.

[17] Krishnamurti, G. S. R., Huang, P. M., Kozak, L. M. (1999): Desorption kinetics of cadmium from soils using $\mathrm{M}$ ammonium nitrate and $\mathrm{M}$ ammonium chloride. Communications in Soil Science and Plant Analysis 30: 2785-2800.

[18] Luo, Y., Rimmer, D. L. (1995): Zinc-copper interaction affecting plant growth on a metal-contaminated soil. - Environmental Pollution 88(1): 79-83.

[19] McCauley, A., Jones, C., Jacobsen, J. (2009): Soil pH and Organic Matter. Nutrient Management Modules, Vol. 8. - Montana State University Extension Service, Bozeman, Montana, USA, pp. 1-12.

[20] Özbolat, G., Tuli, A. (2016): Effects of heavy metal toxicityon human health. - Archives Medical Review Journal 25(4): 502-521.

[21] Pandolfini, T., Gabbrielli, R., Comparini, C. (1992): Nickel toxicity and peroxidase activity in seedlings of Triticum aestivum L. - Plant, Cell \& Environment 15: 719-725.

[22] Paulin, B., O'Malley, P. (2008): Compost Production and Use in Horticulture. - Bulletin 4746. Department of Agriculture and Food, Western Australia, Perth.

[23] Ramachandran, V., D'souza, S. F. (2013): Adsorption of nickel by Indian soils. - Journal of Soil Science and Plant Nutrition 13(1): 165-173.

[24] Saltalı, K., Eryiğit, N. (2015): Farklı Linyit Kömüründen Elde Edilen Humik Asidin Bazı Toprak Özellikleri ve Bitki Gelişimine Etkisi. - KSÜ Doğa Bilimleri Dergisi, Özel Sayı, pp. 60-65. 
[25] Saltal1, K., Dereli, N., Kizılkaya, R. (2015): Effects of gyttja on some soil quality parameters. - International Soil Science Congress on "Soil Science in International Year of Soils 2015". 19-23 October 2015, Sochi, Russia. Book of Proceedings, pp. 363-367.

[26] SAS Institute (1989): SAS User's Guide. Statics. Version 6,4+4 ed Vol. 2. - SasInstitute, Cary. NC.

[27] Stevenson, F. J (1994): Humus Chemistry. Genesis, Composition, Reactions. - Wiley, New York.

[28] Tan, K. H. (2003): Humic Matter in Soil and the Environment. Principles and Controversies. - Marcel Dekker, New York.

[29] Turgay, O. C., Karaca, A., Unver, S., Tamer, N. (2011): Effects of coal-derived humic substance on some soil properties and bread wheat yield. - Communications in Soil Science and Plant Analysis 42(9): 1050-1070.

[30] Usman, A. R. A., Kuzyakov, Y., Stahr, K. (2008): Sorption, desorption, and immobilization of heavy metals by artificial soil. - MSc. Thesis, University of Hohenhiem, Stuttgart.

[31] Zhao, K. L., Liu, X. M., Xu, J. M., Selim, H. M. (2010): Heavy metal contaminations in a soil-rice system: identification of spatial dependence in relation to soil properties of paddy fields. - Journal of Hazardous Materials 181: 778-787. 